\title{
PSYCHOLOGICAL CONDITION AND RESOCIALIZATION OF WIDOWS AND GRIEVING MOTHERS IN CONDITIONS OF MODERN UKRAINE
}

\author{
Olena Kostyuk $^{1}$, Olena.Boychuk ${ }^{2}$ \\ 1P.L Shupyk National Medical Academy of Postgraduate Education, National University of \\ "Kyiv Mohyla Academy", Kyiv, Ukraine \\ ${ }^{2}$ National University of "Kyiv Mohyla Academy", Vadym Hetman Kyiv National Economic \\ University, Kyiv, Ukraine
}

Introduction. Personal development in competitive and adverse conditions gives us plenty of examples that show negative behavior and incapability of making peace between nations. The situation in the world today confirms the previous statement, Ukraine suffers more than many other countries because of the powerful neighbor from the East who forces our country to accept his conditions. The war in Eastern Ukraine is the consequence of this irrational and atavistic tendency. We are the victims of the aggravation between two dialectic processes of social activism: disconnection (destructive situations, ATO, loss of a family member, family break up, heightened level of aggression in the community) connection (constructive and creative appearances, adaptation in conditions of forced immigration, posttraumatic growth, resocialization after overcoming trauma, tendency for reconciliation, personal growth in a new profession).

This is the reality that requires psychological science and practice to find quick and accurate answers because the goal is to save people's mental health in military and mobilization conditions.

Purpose. The main goal of the research is to generalize the information about psychological features of the people who have experienced loss. Also to spot the stages of women's post-loss resocialization and factors that have a positive impact on that resocialization.

Methodology. The authors of this paper made research on the psychological features of the people who have experienced loss due to military situation in the East of Ukraine and who need psychotherapy to help the process of resocialization. The facts stated in the paper that helped to analyze the situation were received during work in the period of 2015-2018 at the center of psychosocial rehabilitation at National University of "Kyiv Mohyla Academy". 5370 people have addressed to the center to get help during this period. 1414 of them have gotten individual consultations, 3953 have participated in group therapies. The gender phenomena was discovered, women address for help more than men. We have also analyzed and classified the reasons that make people address for help and discovered the levels of impact caused by loss. The paper also presents the methods that the center uses in their work.

In the past three years, we have created 3 special groups of psychotherapy for those people who have faced loss, each group had about 6-8 meetings. One third of those who have gone through individual and group therapy also took part in stabilizing group events of our center, like " Magic of breathing", "Soma-relax", 
"Right hemisphere drawing" or "Mandala therapy", patients visited our playback theater and also came for a consult because of problems with children.

We used CETA: Common Elements Treatment Approach, the program that has two forms of psychotherapy, a short-term with 5 sessions, middle term with 8-12 sessions. CETA uses cognitive behavioral therapy methods and is lead by the JHU Applied Mental Health Research group. We made a screening research on women who had psychotherapy to monitor their condition, the screening was made with the help of "mental health quiz КМА-УДХ). The screener was received from the JHU Applied Mental Health Research Group and adapted for use in Ukraine by the employees of National University of "Kyiv Mohyla Akademy" Psycho-social Rehabilitation Center.

Results. While observing the process of secondary socialization after loss we can state that it has two stages.

The first stage is desocialization, it is the opposite to socialization, this part of the process is based on the fact that women need to change their social role, from wife to widow. Women have to reject their previous gender-role model as mother, wife, housewife, employee, her habits and skills to make a transition to a new stage because those usual roles become impossible or divergent in a new status.

We have often observed total or almost total social isolation, minimization of action that only maintains life in family or work system on the smallest level.

Many patients give up on their social interactions and opportunities, their faith, ideology, life values change completely. They experience a full range of reactions from devaluation of their personality, their life and life of their closest people to devaluation of life in general, micro and macro-social environment of a widow or a mother who lost her child.

Psycho-emotional condition of women experiences many changes, they avoid joy and feel constant pressure, they try to come back to grief again but in a new symbolic status.

The next stage is resocialization. The moment when women come back to their usual life but in new circumstances resocialization happens. It can be either under social pressure or because of inner desire.

Conclusions. Our experience that is based on individual and group psychotherapy shows that resocialization starts under pressure, women have to come back to their work and duties because of needs.

Social stigmatization of widows and mothers who lost their children on war leads to creating new social communities where women have support and comfort, where they feel unity. After this women enter a different stage of socialization, many of them change the social environment or job, life position and some aspects of their personality.

This way we consider desocialization and resocialization as parts of the socialization process, to be specific "secondary socialization". It occurs after a serious loss of someone close and requires a significant overview of old social habits and functions. Society plays an important role in secondary socialization process: nation, family, and environment.

The results of the research stated in this paper we recommend to spread around and use in practice. Also, there are created different suggestions on how to improve the quality and success of resocialization.

\section{On the government level}


To refine the government politic about supporting families who lost their closest people.

Social advertisement that honors the lives of the dead. Advertise that sets a healthy relationship with the family who lost their beloved people, not stigmatizing one.

Adding a ritual of honoring the lives of the fallen to national celebrations and important dates.

Creating the virtual memory book of the dead by the Ministry of Defence.

2. On the mass level.

Rituals of honoring the memory of the dead and their families.

Non-formal support. Creating support groups that can help to compensate lost opportunities or to fight social isolation, etc. also different kinds of support on the micro-social level can be helpful.

Formation of specific moral and ethical principles that can help to build a healthier and stronger relationship with those families who lost one of their closest people.

Social flash-mobs like "join mom of your lost friend for a tea", "be a Santa Claus for your dead's friend children", "share the warmth of your heart", "teach a son of your dead friend how to play football or how to drive a nail".

3. On the professional level.

All widows and parents of the dead ATO members need to have a right for professional, prolonged, free of charge help in psycho-social rehabilitation centers.

For those specialists who work with the mentioned type of clients have been created specific supervising systems that prevent emotional burnout.

Special analytical and monitoring systems created in order to know the effectiveness of the treatment.

Methodical and educational training centers for psychologists who specialize on crisis.

Resocialization of those who have faced military loss has to stop being just a personal problem, it is a problem of a nation and by participating in this process we help to overcome desocialization and save the mental health of the nation and its humanization

Keywords. military losses, mental effects, types of lesions, gender characteristics, means of assistance and re-socialization 